\title{
Are interest rate changes comoving with financial cycle?
}

\author{
PAWEE SMAGA*
}

SGH Warsaw School of Economics, al. Niepodległości 162, 02-554 Warsaw, Poland

Received: August 30, 2018 • Revised manuscript received: November 17, 2018 • Accepted: May 31, 2020

(c) 2021 Akadémiai Kiadó, Budapest

\begin{abstract}
We explore to what extent official interest rate changes can potentially in a procyclical manner impact different financial cycle indicators (credit/GDP, debt service ratio, house prices and stock market indices). We test this on data covering 1995-2016 in 21 countries and the euro area using the Concordance index and Monetary policy procyclicality ratio. Results show that this was not a widespread phenomenon, but there was significant heterogenenity across countries. The procyclicality of interest rate changes was usually higher when financial cycle gaps were increasing and lower when they were decreasing. On average, central banks in several larger economies were running potentially less procyclical monetary policy than those in the smaller ones. The resulting propensity of conflicts between achieving price and financial stability by central banks was low, as only in $10 \%$ of the cases the objectives were conflicting (usually when inflation was below the target and the credit cycle was in an expansion phase).
\end{abstract}

\section{KEYWORDS}

financial stability, monetary policy, financial cycle, macroprudential policy, price stability

\section{JEL CLASSIFICATION INDICES}

E52, E58, E61, G18

\section{INTRODUCTION}

The global financial crisis (GFC) underlined the importance of financial stability. Monetary policy proved to be insufficient in safeguarding the stability of the financial system on its own, as

\footnotetext{
*Corresponding author. E-mail: psmaga@sgh.waw.pl
} 
well as might have additionally fuelled the accumulation of imbalances on the asset markets. To safeguard financial stability, macroprudential policy has emerged as an indispensable pillar of economic policy (Mérö 2017). The research on its design and instruments is young and blossomed after the outbreak of the GFC. Subsequently, the financial stability mandates of central banks have been strengthened. Therefore, following the creation of macroprudential authorities in many countries, there is an urgent need to explore the interactions between monetary policy and financial cycle.

The literature on the coordination between monetary and macroprudential policies is still relatively nascent, and there are very few studies that empirically deal with this issue or focus on the interactions between the targets of those policies (e.g., Angelini et al. 2012; Dell'Ariccia et al. 2014; Agénor - da Silva 2014; Smets 2014; Angelini et al. 2014; Malovaná - Frait 2016).

The aim of this paper is to contribute to this stream of research by analysing procyclicality of interest rate changes (henceforth, called monetary policy procyclicality) towards the financial cycle, as proxied by different financial variables used in the literature. By constructing simple monetary policy procyclicality ratios, we analyse the propensity of the 'side-effects' of monetary policy (negatively impacting the financial cycle e.g., by fuelling the financial cycle in its upswing phase or by further depressing it in its downturn phase).

First, we look from the perspective of financial cycle gap and assess whether monetary policy is more procyclical towards the financial cycle measured as: the credit/GDP gap; the real estate cycle, the stock market cycle or debt service ratio (DSR) cycle. Answering this question would give us an indication of the priority areas for the macroprudential policy.

Second, we approach the problem from a policy perspective and measure in which phase of the financial cycle the conflict between price and financial stability is potentially the largest. This is a key question for central banks engaged in maintaining price stability (using monetary policy) and at the same time being obliged to safeguard financial stability (by e.g., implementing macroprudential policy). We analyse only the cyclical component of systemic risk i.e., financial cycle fluctuations, without assessing the impact of monetary policy on structural systemic risk or interconnectedness. We test our hypothesis on the country sample covering 21 countries and the euro area using quarterly data for the period of 1995Q1$2016 \mathrm{Q} 2$.

The paper further refines the methodology proposed in Kurowski - Smaga (2018) by introducing significant expansions, as we i) use a much larger country sample, ii) deploy four instead of one - financial cycle indicators, and iii) calculate the monetary procyclicality ratio in two - instead of one - versions.

Our results show that the procyclicality of monetary policy (changes in central bank rates) towards financial cycle is limited. This directly translates into low propensity of conflicts between the targets of monetary and macroprudential policies, which we explore empirically based on the theoretical framework developed by Beau et al. (2012). Such approach is in contrast to most studies present in the literature using the Dynamic Stochastic General Equilibrium (DSGE) framework. From the perspective of policymakers, such analysis is crucial to provide optimal policy mix, thus minimizing the risk of ineffectiveness of both policies. We show that the price and financial stability objectives were conflicting only in $10 \%$ 
of the cases, typically when inflation was below the target and the credit cycle was in expansion.

The paper is organised as follows. In Section 2, we review the literature on procyclicality and interactions between monetary policy and cyclical systemic risk to identify the research gaps. In Section 3, we present the method used to assess the procyclicality ratio of monetary policies, as well as the data. In the subsequent Sections, we analyse and discuss the results of monetary policy procyclicality and propensity of conflicts between financial and price stability, while Section 7 concludes.

\section{LITERATURE REVIEW}

Many studies analysed the impact of monetary policy on the business cycle, while very few focused on the potential implications of monetary policy on the financial cycle itself. Financial cycles have different characteristics than economic cycles. Financial cycles have a medium-term character, are deeper, longer and have a much greater amplitude than business cycles (Borio 2014). Yet, there are considerable interlinkages between both types of cycles (Kollintzas et al. 2011), as financial cycle peaks are closely associated with financial crises and the recessions resulting from house and equity price busts tend to be deeper and longer than other recessions (Claessens et al. 2011).

There are many channels through which the monetary policy impacts financial stability, which underlines the importance of analysing the effects of monetary policy on the financial cycle. The basic channels include bank funding and lending, balance sheet and profitability, bank capital and risk-taking channels (Beyer et al. 2017). The central bank's policy involving liquidity programs can, via the balance sheet channel, increase banks' leverage and contribute to disproportionate asset price growth (Landier et al. 2011). Interest rate increases in the free capital movement environment (e.g., in response to excessive credit growth) may lead to an increase of foreign capital inflows, which via currency exchange appreciation may in turn increase the risk of foreign currency exposures. Prolonged expansive monetary policy induces the over-indebtedness of households (Persson 2009), thus increasing credit risk (Gersl et al. 2015; Maddaloni - Peydró 2013), and promotes the search for yield behaviour (Nicolò et al. 2010) through the risk-taking channel. Similarly, Jiménez et al. (2014) and Heider et al. (2018) prove that low interest rates lead to higher bank leverage and encourage risk-taking. This shows that analysing the impact of monetary policy on business cycles alone might underestimate its effects on the financial factors.

Such interrelations call for coordination between the monetary and macroprudential policies. Dell'Ariccia et al. (2014) argue that close to the financial cycle peak there is no trade-off between those policies, as monetary tightening will reduce both banks' risk appetite and inflationary pressure. However, the trade-off is more pronounced when financial imbalances are building up, inflation is within the target, and thus, the restrictive monetary policy would excessively dampen the economic outlook and consumer prices. This dilemma is a key for a central bank with a dual mandate, as such trade-off implies that interest rate influences financial stability. Central banks' price and prudential mandates are interrelated because most macroprudential tools (e.g., capital buffers) at least partially operate through the monetary policy transmission channels (Agénor - da Silva 2014). 
Conflicts between different aims and instruments of monetary and macroprudential policies are confirmed by a growing number of empirical studies. Such case is explored by Igan et al. (2017), who show that monetary policy has statistically significant effects on the balance sheets of banks, yet monetary tightening alone (increases of interest rates) is unlikely to be sufficient to stem the house price boom. Further, Miles (2014), Crowe et al. (2013) and Shi et al. (2014) show that the monetary policy rates have little impact on house prices (due to e.g., influence of external factors), thus making the macroprudential policy indispensable, not substitutive, to effectively stem the house price booms. This is echoed by Rubio (2016), who argues that in the short-term, monetary policy can improve financial stability only at the cost of more macroeconomic volatility, but the effectiveness of monetary policy in stabilizing the economy and the financial system diminishes in the long term. Greenwood-Nimmo - Tarassow's (2016) prove that while macroprudential policy alone has an ambiguous impact on financial stability, the restrictive monetary policy aggravates financial fragility, and so a combination of both policies might be more effective. Additionally, when the interest rate targeting rule focuses only on inflation, it may exacerbate the asset price cycle (as historically asset booms have mainly been associated with low inflation) but adding the credit component to the interest rate targeting rules would help limit the volatility (Christiano et al. 2010).

\section{DATA AND METHODOLOGY}

Our sample consists of quarterly data for 16 developed countries, ${ }^{1}$ along with the euro area and for 5 developing countries ${ }^{2}$ over the period of 1995Q1-2016Q2. From the Bank of International Settlements (BIS) Database we collect the data for the credit/GDP ratios (outstanding credit to the non-financial sector), debt service ratios for the private non-financial sector, and residential nominal house prices. The data for main stock market indices (SMI) are collected predominantly from national stock exchange websites. We use those variables to assess the cyclical behaviour of monetary policy towards four proxies of financial cycles: credit/GDP (credit cycle), debt service ratios (DSR cycle), nominal house prices (NHP cycle) and the natural logarithm of the stock market index (SMI cycle) in each country. Based on the literature, these variables should be considered as adequate financial cycle measures, showing cyclical swings of credit, indebtedness of the economy, real estate cycles and stock market fluctuations (Borio et al. 2010; Drehmann - Juselius 2013; Plašil et al. 2016).

We calculate the trends for four financial cycle measures using the Christiano-Fitzgerald (CF) filter with a band of 32-120 quarters, thus assuming the length of the financial cycle between 8 and 30 years suggested by Borio et al. (2012). Such an approach is in line with the methodology established in the literature for measuring credit cycles (Detken et al. 2014; Jong Sakarya 2016; Samarina et al. 2017). We do not use the popular Hodrick-Prescott filter as it has known drawbacks, e.g., the risk of identifying false dynamic relations and the end-point problem (Hamilton 2018). For each financial cycle proxy, we compute and analyse the output of CF filter in EViews - the cycle component called the financial cycle gap (i.e., creditgap, DSRgap, NHPgap, SMIgap) for each country in each quarter in the sample.

\footnotetext{
${ }^{1}$ Austria, Belgium, Denmark, Finland, France, Germany, Italy, Japan, the Netherlands, Norway, Portugal, Spain, Sweden, Switzerland, the United Kingdom and the USA.

${ }^{2}$ China, Czech Republic, Hungary, Korea and Poland.
} 
Further, for the assessment of monetary policy, we use quarterly inflation rates from OECD Data and the central bank websites. As a proxy for monetary policy decisions, we analyse the official central bank interest rates, assuming the level of quarterly interest is given as an average of daily rates - also collected from the national bank websites. The detailed description of data sources is included in the Appendix.

To the four variables representing the financial cycle, we apply empirical normalization using the common min-max methodology:

$$
I_{i t}^{n}=\frac{I_{i t}-\min \left(I_{i}\right)}{\max \left(I_{i}\right)-\min \left(I_{i}\right)}
$$

where $I_{i t}^{n}$ is normalized variable $i$ in period $t$, and $\max \left(I_{i}\right)$ and $\min \left(I_{i}\right)$ are, respectively, the maximum and minimum values of the variable $i$. Therefore, the normalized variables' values range between 0 and 1 . Normalized variables are then combined into our proposal of an aggregated index - the financial stability index (FSI):

$$
\text { Financial stability index }=w_{1} \text { creditgap }+w_{2} \text { DSRgap }+w_{3} \text { NHPgap }+w_{4} \text { SMIgap }
$$

where $w_{i}$ are weights applied for each normalized variable. The literature does not provide a comprehensive and universal way to assign weights for each variable. However, we test the use of the weights resulting from the Principal Component Analysis (PCA) ${ }^{3}$ that reflect the importance of index components. Some researchers (Hakkio - Keeton 2009; Klomp - de Haan 2012; Cevik et al. 2013; Siņenko et al. 2014; Dumičić 2016; Iwanicz-Drozdowska et al. 2017; ECB 2018) use PCA for setting weights for financial indices similar to ours, so we follow this approach. The average PCA-weights for FSI variables in our dataset range from 0.244 to 0.256 . Therefore, basing on such results, for comparative reasons we finally assign equal weights of 0.25 for each variable $^{4}$ in the FSI, which is almost the same as those from PCA. Equal weighting scheme is also one of the methods often applied by the central banks to their FSIs built on the micro banking data. Similar weights for banking sector and house market subindices in the financial cycle indicator were estimated by Kota - Saqe (2013), as well as for subindices in Albulescu (2010). Additionally, equal weights were used, as we do, for subcomponents of financial stress indices constructed in the literature (Lo Duca - Peltonen 2013; Jakubík - Slačík 2013; Kota - Saqe 2013; Vermeulen et al. 2015; Szendrei - Varga 2017).

Next, we analyse the monetary policy stance focusing on changes in interest rates, not their levels per se. Such approach is motivated by the fact that the given (numerical) interest level - basing on the historical interest rate paths - might be considered low in a particular country and high in the other country at the same time. Therefore, for comparative reasons we use interest changes instead. For the purpose of the study, expansive monetary policy is defined as a period (number of quarters) when interest rates are decreasing. Restrictive monetary policy is defined as the opposite. Having in mind that interest rates and their changes are not the only indicator of monetary policy stance, when using the "monetary policy procylicality" we mean potential procyclical change in the official

\footnotetext{
${ }^{3}$ We use the PCA approach to determine a low number of unobserved factors that explain the highest possible share of variance in the data. Following Guttman-Kaiser's rule, we retain only those characteristics with eigenvalues greater than 1.

${ }^{4} \mathrm{An}$ attempt to assign different weights (ranging from e.g. 0.1 to 0.4 for a given ratio) to the five financial ratios yields comparable results concerning monetary policy procylicality towards FSI. The results of FSI with PCA weights are available upon request.
} 
interest rates. Due to the constraints concerning lack of comparable data we are unable to include other elements of monetary policy stance in a consistent manner.

We assess the procyclicality of monetary policy in two different approaches.

First, we apply the concordance index - CI, proposed by Harding - Pagan (2001), is defined as:

$$
C I_{x y}=\frac{1}{T} \sum_{t=1}^{T}\left[S_{t}^{x} S_{t}^{y}+\left(1-S_{t}^{x}\right)\left(1-S_{t}^{y}\right)\right]
$$

where:

$$
\begin{aligned}
& S_{t}^{x}=\left\{\begin{array}{l}
1, \text { if monetary policy is expansive } \\
0, \text { if monetay policy is restrictive }
\end{array}\right. \\
& S_{t}^{y}=\left\{\begin{array}{l}
1, \text { if financial cycle gap increases } \\
0, \text { if financial cycle gap decreases }
\end{array}\right.
\end{aligned}
$$

The index defines the procyclical stance of monetary policy, when monetary policy is expansive while financial cycle gaps are increasing. In this situation interest rate cuts fuel expanding financial cycle gaps, adversely affecting the cyclical systemic risk. When the financial cycle gap contracts, the expansive monetary policy is countercyclical and supports the revival of the given financial cycle. Moreover, a restrictive monetary policy has a procyclical effect when financial cycle gaps decrease at the same time. When financial cycle gaps increase, the restrictive monetary policy is countercyclical and limits the build-up of credit bubbles.

CI index can alternatively be derived (Harding - Pagan 2001) the other way basing on synchronization between the sample of two cyclical series " $A$ " and " $B$ " denoted as $C_{t}^{A}$ and $C_{t}^{B}$ :

$$
C I=1+2 \rho_{C} \sigma_{C, A} \sigma_{C, B}+2 \mu_{C, A} \mu_{C, B}-\mu_{C, A}-\mu_{C, B}
$$

where, $\mu_{C}$ is a mean and $\sigma_{C}$ is a standard deviation of a particular cycle, and $\rho_{C}$ denotes correlation between them. $\rho_{C}$ is calculated using OLS regression:

$$
\left(\frac{C_{t}^{A}}{\sigma_{C, A}}\right)=\beta+\rho_{C}\left(\frac{C_{t}^{B}}{\sigma_{C, B}}\right)+\varepsilon_{t}
$$

Our CI indicator reaches values from 0 to 1 . The value of 1 indicates that monetary policy is conflicting (procyclical) with the financial cycle (i.e., interest rate increases when financial cycle gap decreases, or interest rate decreases when financial cycle gap increases). The value of 0 indicates the supportive (countercyclical) role of monetary policy towards the financial cycle (i.e., interest rate increases when financial cycle gap increases, or interest rate decreases when financial cycle gap decreases).

Second, we use the monetary policy procyclicality ratio (MPP), basing on a dynamic approach proposed by Kurowski - Smaga (2018).

We assume that we are not able to assess the procyclical behaviour of monetary policy (expansive and restrictive) when the financial cycle gaps (positive or negative) become smaller on a quarterly basis (see Table 1 ).

When a positive financial cycle gap is decreasing, the expansive monetary policy may work in a countercyclical way, as such tendency indicates a financial cycle slowdown. However, there is still a positive gap. In this situation we assume that the impact of monetary policy on the 
Table 1. Monetary policy and financial cycle gap

\begin{tabular}{|l|c|c|c|c|}
\hline \multirow{2}{*}{ Monetary policy $\backslash$ Gap } & \multicolumn{2}{|c|}{$\begin{array}{c}\text { Positive gap in quarter } \boldsymbol{i} \text { higher than } \\
\mathbf{2 0 \%} \text { of maximal gap level }\end{array}$} & $\begin{array}{c}\text { Negative gap in quarter } \boldsymbol{i} \text { lower than } \\
\mathbf{2 0 \%} \text { of minimal gap level }\end{array}$ \\
\cline { 2 - 5 } & $\Delta$ gap $>\mathbf{0}$ & $\Delta$ gap $<\mathbf{0}$ & $\Delta$ gap <0 & $\Delta$ gap $>\mathbf{0}$ \\
\hline Expansive in quarter $\boldsymbol{i}$ & Procyclical & Undefined & Counterclical & Undefined \\
\hline Restrictive in quarter $\boldsymbol{i}$ & Counterclical & Undefined & Procyclical & Undefined \\
\hline
\end{tabular}

Source: Own work based on Kurowski - Smaga (2018).

financial cycle is undefined. Therefore, we propose that an expansive monetary policy works in a procyclical way only when at the same time the financial cycle gap is positive and increases on a quarterly basis $(\Delta$ positive gap $>0$ ) i.e., interest rate cuts fuel expanding financial cycle gap. Similar assumption is made in the case of a restrictive monetary policy. When a negative financial cycle gap is closing, the restrictive monetary policy could work in a countercyclical way, as such tendency could indicate a future financial cycle boom, but on the other hand, there is still a negative gap. Therefore, a restrictive monetary policy works as procyclical only when the negative financial cycle gap is expanding on a quarterly basis.

Additionally, we consider the monetary policy approach towards the financial cycle as undefined when the financial cycle gap is close to its long-run trend (i.e., the gap value is small and close to 0 ). In this way, we want to exclude financial cycle deviations close to the equilibrium (trend) that do not pose an immediate risk to financial stability and would not mark a shift in the tendency. We consider only significant deviations from the trend (i.e., high gaps) to pose cyclical risks. Thus, financial cycle gaps within the equilibrium range (between lower and upper bands) are excluded from the further analysis. The lower band (below the trend i.e., for the negative gaps) is $20 \%$ of the minimum of the given financial cycle gap, while the upper band (above the trend i.e., for the positive gaps) is $20 \%$ of the maximum thereof. The equilibrium range around the trend is thus defined as follows ${ }^{5}$ :

$$
0.2[\min (\text { gap })]<\text { trend }<0.2[\max (\text { gap })]
$$

Therefore, the MPP in each country based on the second approach is calculated as:

$$
\mathrm{MPP}=\frac{\sum_{i=1}^{t} k_{t}}{n} \times 100 \%
$$

where $n$ is the total number of observations and $k_{t}$ is described as follows:

$$
k_{t}=\left\{\begin{array}{c}
1, \quad \text { when monetary policy is procyclical in quarter } t \\
0, \text { otherwise }
\end{array}\right.
$$

In the end, the MPP simply shows the share of quarters in the whole sample period when monetary policy is procyclical. As indicated above, monetary policy is deemed procyclical only in

\footnotetext{
${ }^{5}$ As the aggregated index (FSI) basing on normalized financial cycle measures fluctuates between 0 and 1 , the equilibrium range for the FSI is set between 0.4 and 0.6 .
} 
quarters when interest rate increases are concurrent with the increase in the positive financial cycle gaps or when interest rate cuts are concurrent with the improvement of the negative financial cycle gaps. The MPP reaches values from 0 to 1 . The lower the level of the MPP, the smaller the potential conflicts between monetary policy and the given financial cycle phase. Consequently, the higher the level of the MPP is, the stronger the potential procyclical behaviour of monetary policy.

As the impact of interest changes on the economic activity, and thus, financial stability is not immediate, we include monetary transmission output lags in the analysis. For consistency purposes, we assume the monetary transmission lag (the lag between the interest rate change and its impact on the financial cycle measure) in the analysed countries equals four quarters, which is an average period basing on the analyses of the monetary policy transmission mechanisms by central banks (Hopkins et al. 2009).

\section{ANALYSIS OF MONETARY POLICY PROCYCLICALITY}

The analysis of trends in the financial cycle measures over the whole sample ${ }^{6}$ leads to several conclusions. Most countries in the sample have sizable and developed banking sectors i.e., high credit/GDP ratios. There is a strong (and statistically significant) negative correlation between the average positive and negative gaps in the whole sample. Therefore, the countries experiencing vigorous booms in the financial cycles are likely to be subject to equally strong busts. The peaks (Fig. 1) in the stock market cycles were clearly visible in all analysed countries during the dot-com bubble (end of 2000) and at the start of the GFC (end of 2007). The most volatile gaps are observed for the stock market indices. The potential amplitude of the cyclical gap

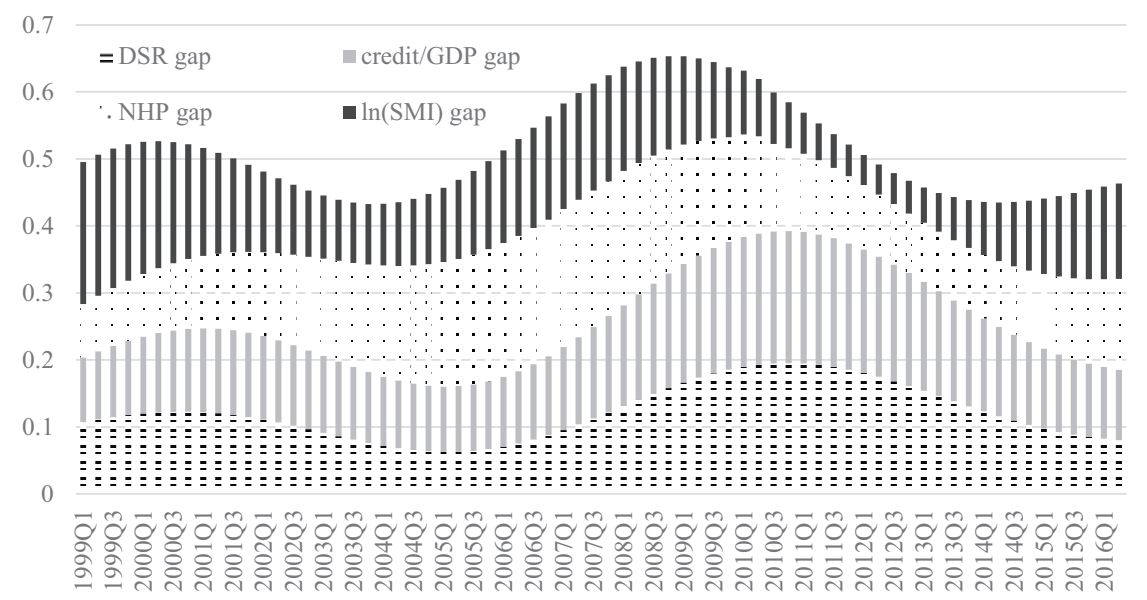

Fig. 1. Aggregated financial cycle gaps for all countries 1999-2016

Note: All gaps are normalized. Simple averages and equal weights for each gap (0.25).

Source: Own work.

${ }^{6}$ Detailed statistics are available from the author upon request. 
fluctuations does not seem to be correlated with the size of the banking sector, the level of household indebtedness or the residential house price level. This indicates that the financial cycles are present at all levels of financial system development in the countries in the sample.

Having estimated the gaps for all four financial cycle measures and defined the monetary policy stance (using changes in the interest rates), we calculate the monetary policy procyclicality ratios (CI and MPP). The results are analysed on three levels: i) country, ii) financial cycle measure and iii) time. The values of both the MPP and CI might be interpreted as a scale of monetary policy procyclicality (share of quarters) in the sample with a given financial cycle phase (recovery, boom, bust and slowdown). Higher values represent higher potential monetary policy procyclicality (Table 2 ).

In general, the CI produces higher procyclicality ratios than the MPP in almost all countries. This is due to the differences in the construction methodologies of both ratios. The average CI values range from 0.21 to 0.35 , while those of the MPP from 0.1 to 0.12 . This proves that the potential procyclicality of monetary policy is not a widespread phenomenon and exists in significantly less than one third of the analysed quarters. In the case of the MPP ratios, on average, there are no differences in monetary policy procyclicality towards the particular measures of the financial cycle, while for CI slightly higher procyclicality is visible towards NHP and SMI. This might reflect a more robust procyclical response of the stock market cycle to the interest rate changes (as shown by Rigobon - Sack 2004; Bjørnland - Leitemo 2009). Yet, the potentially higher procyclicality of the monetary policy towards the real estate prices does not at the same time confirm the strength of the transmission mechanism. As Miles (2014), Crowe et al. (2013) and Shi et al. (2014) argue, monetary policy has a little direct impact on house prices.

On average, higher procyclicality in the CI ratios for DSR, credit/GDP, NHP and SMI is identified in Hungary, Sweden and China, while for the MPP ratios in Denmark, Hungary and Sweden. These countries have experienced relatively high gaps in the financial cycle measures, run independent national monetary policy and are open economies vulnerable to external shocks and the global financial conditions. In contrast, smaller average CI values are found in Japan and advanced economies (e.g., the USA, the United Kingdom, Switzerland) and for the MPP in Japan, the USA, the euro area and the developed countries like Finland, France and Italy. This shows that the larger economies, with more developed monetary policy frameworks might be more effective in running a less procyclical monetary policy. Comparing the average values of CI and MPP between the developed and developing countries in the sample ${ }^{7}$ reveals slightly higher values of those ratios for the developing countries, which confirms the abovementioned conclusion.

When assessing the development of procyclicality ratios over time, ${ }^{8}$ both the MPP and CI point to the high procyclicality of monetary policy towards DSR and credit/GDP in 2009/2010 in a vast majority of the analysed countries. The procyclicality of monetary policy is usually higher when the financial cycle gaps are increasing and lower when they are decreasing. This might be due to the stronger impact of the financial cycle (deleveraging) on the business cycle in

\footnotetext{
${ }^{7}$ Unweighted average values of CI and MPP equal (respectively) 0.27 and 0.9 for the developed countries and 0.34 and 0.14 for the developing countries.

${ }^{8}$ Detailed heatmaps are available from the author upon request.
} 
Table 2. Procyclicality ratios for the whole sample and all financial cycle measures

\begin{tabular}{|c|c|c|c|c|c|c|c|c|c|c|c|c|c|}
\hline & Ratio & DSR & FSI & Credit/GDP & NHP & SMI & & Ratio & DSR & FSI & Credit/GDP & NHP & SMI \\
\hline \multirow[t]{2}{*}{ Austria } & $\mathrm{Cl}$ & $n / a$ & $n / a$ & 0.149 & 0.338 & 0.448 & \multirow[t]{2}{*}{ Portugal } & $\mathrm{Cl}$ & 0.224 & 0.134 & 0.239 & 0.373 & 0.269 \\
\hline & MPP & $n / a$ & $\mathrm{n} / \mathrm{a}$ & 0.119 & 0.231 & 0.104 & & MPP & 0.119 & 0.104 & 0.134 & 0.119 & 0.045 \\
\hline \multirow[t]{2}{*}{ Belgium } & $\mathrm{Cl}$ & 0.313 & 0.224 & 0.179 & 0.209 & 0.448 & \multirow[t]{2}{*}{ Spain } & $\mathrm{Cl}$ & 0.203 & 0.290 & 0.293 & 0.293 & 0.415 \\
\hline & MPP & 0.254 & 0.030 & 0.104 & 0.015 & 0.045 & & MPP & 0.029 & 0.118 & 0.061 & 0.122 & 0.183 \\
\hline \multirow[t]{2}{*}{ Denmark } & $\mathrm{Cl}$ & 0.348 & 0.391 & 0.378 & 0.512 & 0.372 & \multirow[t]{2}{*}{ Sweden } & $\mathrm{Cl}$ & 0.232 & 0.348 & 0.320 & 0.560 & 0.493 \\
\hline & MPP & 0.191 & 0.147 & 0.159 & 0.110 & 0.103 & & MPP & 0.101 & 0.087 & 0.160 & 0.280 & 0.173 \\
\hline \multirow[t]{2}{*}{ Euro area } & $\mathrm{Cl}$ & 0.164 & 0.224 & 0.254 & 0.328 & 0.373 & \multirow[t]{2}{*}{ Switzerland } & $\mathrm{Cl}$ & 0.129 & 0.161 & 0.210 & 0.371 & 0.177 \\
\hline & MPP & 0.045 & 0.015 & 0.075 & 0.104 & 0.045 & & MPP & 0.097 & 0.097 & 0.129 & 0.161 & 0.032 \\
\hline \multirow[t]{2}{*}{ Finland } & $\mathrm{Cl}$ & 0.217 & 0.188 & 0.207 & 0.256 & 0.366 & \multirow[t]{2}{*}{ United Kingdom } & $\mathrm{Cl}$ & 0.188 & 0.232 & 0.244 & 0.268 & 0.146 \\
\hline & MPP & 0.087 & 0.043 & 0.049 & 0.049 & 0.073 & & MPP & 0.059 & 0.232 & 0.171 & 0.110 & 0.085 \\
\hline \multirow[t]{2}{*}{ France } & $\mathrm{Cl}$ & 0.194 & 0.134 & 0.134 & 0.269 & 0.388 & \multirow[t]{2}{*}{ USA } & $\mathrm{Cl}$ & 0.174 & 0.159 & 0.183 & 0.232 & 0.268 \\
\hline & MPP & 0.119 & 0.030 & 0.090 & 0.060 & 0.060 & & MPP & 0.014 & 0.000 & 0.024 & 0.085 & 0.061 \\
\hline \multirow[t]{2}{*}{ Germany } & $\mathrm{Cl}$ & 0.239 & 0.403 & 0.299 & 0.448 & 0.284 & \multirow[t]{2}{*}{ China } & $\mathrm{Cl}$ & 0.246 & 0.304 & 0.378 & 0.304 & 0.244 \\
\hline & MPP & 0.075 & 0.179 & 0.119 & 0.269 & 0.060 & & MPP & 0.174 & 0.182 & 0.293 & 0.182 & 0.134 \\
\hline \multirow[t]{2}{*}{ Italy } & $\mathrm{Cl}$ & 0.254 & 0.209 & 0.254 & 0.269 & 0.478 & \multirow[t]{2}{*}{ Czech Republic } & $\mathrm{Cl}$ & 0.273 & 0.242 & 0.242 & 0.333 & 0.364 \\
\hline & MPP & 0.075 & 0.030 & 0.075 & 0.090 & 0.090 & & MPP & 0.167 & 0.125 & 0.197 & 0.031 & 0.091 \\
\hline \multirow[t]{2}{*}{ Japan } & $\mathrm{Cl}$ & 0.029 & 0.029 & 0.061 & 0.061 & 0.073 & \multirow[t]{2}{*}{ Hungary } & $\mathrm{Cl}$ & 0.362 & 0.486 & 0.378 & 0.649 & 0.549 \\
\hline & MPP & 0.000 & 0.015 & 0.037 & 0.037 & 0.037 & & MPP & 0.147 & 0.083 & 0.098 & 0.222 & 0.280 \\
\hline \multirow[t]{2}{*}{ Netherlands } & $\mathrm{Cl}$ & 0.149 & 0.179 & 0.269 & 0.343 & 0.343 & \multirow[t]{2}{*}{ Korea } & $\mathrm{Cl}$ & 0.242 & 0.258 & 0.318 & 0.318 & 0.242 \\
\hline & MPP & 0.119 & 0.060 & 0.149 & 0.134 & 0.045 & & MPP & 0.106 & 0.106 & 0.152 & 0.091 & 0.030 \\
\hline \multirow[t]{2}{*}{ Norway } & $\mathrm{Cl}$ & 0.188 & 0.304 & 0.317 & 0.366 & 0.500 & \multirow[t]{2}{*}{ Poland } & $\mathrm{Cl}$ & 0.348 & 0.320 & 0.314 & 0.320 & 0.500 \\
\hline & MPP & 0.116 & 0.029 & 0.061 & 0.122 & 0.220 & & MPP & 0.162 & 0.000 & 0.186 & 0.125 & 0.214 \\
\hline
\end{tabular}

Source: Own work. 
a bust phase, thus leading to a recession and countercyclical monetary easing, while this relationship might be weaker in booms.

The results of procyclicality ratios towards an aggregated financial cycle measure (FSI) show that it is on average high mainly in Germany and Denmark, with no clear patterns over time. Overall, rather low procyclicality towards FSI masks higher procyclicality of monetary policy towards the particular financial cycle measures.

\section{INTERACTIONS BETWEEN PRICE AND FINANCIAL STABILITY}

After analysing the potential procyclicality of monetary policy towards the financial cycle measures, we conclude that such cases are rather infrequent. Still, there is a need to manage the conflicts central banks face when trying to achieve price and financial stability at the same time. Therefore, we analyse the cyclical component of systemic risk and focus on the potential impact of monetary policy on credit/GDP gaps, as it is the most common measure of the credit cycle and often used by the central banks and macroprudential authorities.

A comprehensive example of potential conflicts between the inflation target and financial cycle (Table 3) has been presented from a theoretical perspective by Beau et al. (2012). We are especially interested in the conflicting objectives i.e., when a credit boom is further procyclically fuelled by low interest rates due to the inflation being below the target. Another conflicting case is when inflation is above the target but increases in interest rates to bring it down coexist with the deleveraging phase of the credit cycle, thus exacerbating the bust. We define a credit boom when the credit/GDP gap is positive and increasing, while bust exists when the credit/GDP gap is negative and decreasing. Other values of the gaps are defined as posing no imbalances (i.e., when the gaps are closing).

We try to empirically explore potential instances of such conflicts between achieving price stability and stabilizing the financial cycle, as did Malovaná - Frait (2016). We follow the approach in Kurowski - Smaga (2018), specifically, for each quarter we compare the level of current inflation rate (above or below the numerical inflation target) with the current phase of the credit/GDP cycle for that quarter, and thus, identify the type of relation between the monetary and macroprudential policy objectives (conflicting/neutral/complementary). ${ }^{9}$ Lastly, we calculate the share of quarters in the total sample with different types of interactions between

Table 3. Potential relations between inflation targeting strategy and financial cycle phase

\begin{tabular}{|l|c|c|c|}
\hline & Inflation above target & Inflation close to target & Inflation below target \\
\hline Financial exuberance (boom) & Complementary & Neutral & Conflicting \\
\hline No imbalances & Neutral & Neutral & Neutral \\
\hline Financial deflation (bust) & Conflicting & Neutral & Complementary \\
\hline
\end{tabular}

Source: Beau et al. (2012).

\footnotetext{
${ }^{9}$ As neutral we regard cases when there are no imbalances i.e. financial cycle gaps are within the equilibrium range and/or at the same time the current inflation rate is within the inflation target range set by the central bank in the given country.
} 
policies. We conduct the analysis under the assumption that the inflation is either above or below the official numerical target, thus necessitating an increase or decrease of interest rates.

The analysis from the policy perspective (Table 4) reveals that in approximately threefourths of cases, the relation between price stability and the financial cycle is neutral. ${ }^{10}$ The objectives in almost one-fifth of quarters are complementary and they are conflicting only in $10 \%$ of cases. The share of quarters with complementary objectives is highest in Hungary, Portugal, Spain and Poland (close to one-third of the observations). Out of all complementary cases, one-third was when inflation was above the target and credit cycle was expanding, thus a restrictive monetary policy would support achieving both price and financial stability. Further, in the other two-thirds, the inflation was below the target and an expansive monetary policy in a decelerating financial cycle would support both objectives at the same time.

In terms of conflicting objectives, they were present predominantly in China (more than $40 \%$ of the quarters), but also in Japan and Switzerland in one-fifth of the cases. In all other countries (except for Korea and Czech Republic), the share of conflicting objectives is $10 \%$ or below. Such conclusion is also a characteristic when analysing the credit/GDP cycle phases in the whole sample, as $87.9 \%$ of the conflicting objectives are present when inflation is below the target and the credit cycle is in expansion. Only in $12.1 \%$ of cases, the conflict is when inflation is above the target in a financial bust. When comparing the average share of particular cases between the developed and developing countries in the sample, we observe slightly higher share of conflicting objectives among the developing (15\%) than in the developed countries (8\%), which translates into lower share of neutral cases (65\%) in the developing countries, than in the developed ones (75\%).

Our results show that the procyclicality of monetary policy towards the financial cycle rarely occurs and the propensity of potential conflicts between price and financial stability when setting interest rates very low and is most visible in a credit boom with the increasing financial cycle gaps. This is in line with the analysis of Angelini et al. (2012) and of Dell'Ariccia et al. (2014) arguing that the trade-off between both objectives is more prominent when cyclical imbalances are accumulating. This points out the importance of deploying the countercyclical macroprudential tools, especially in a boom phase of the financial cycle to stem any potential negative 'side-effects' of procyclical easing in interest rates.

Table 4. Empirical propensity of potential conflicts between objectives of monetary and macroprudential policies - whole sample

\begin{tabular}{|l|c|c|c|}
\hline & Inflation above target & Inflation close to target & Inflation below target \\
\hline Financial exuberance (boom) & $6.5 \%$ & \multirow{2}{*}{$72.4 \%$} & $8.8 \%$ \\
\cline { 1 - 2 } No imbalances & & & \\
\cline { 1 - 2 } Financial deflation (bust) & $1.2 \%$ & & $11 \%$ \\
\hline
\end{tabular}

Note: Values represent the percentage of quarters in the whole sample; sum of all cases equal $100 \%$. Source: Own work.

\footnotetext{
${ }^{10}$ Detailed country-level results are available from the author upon request.
} 
However, we note that the procyclicality of monetary policy towards different financial cycle measures is mixed at the same time. It thus shows that interest rate changes might affect different types of financial cycles in an asynchronous way. We can support the conclusion of Šlahor et al. (2015) that due to a lack of financial cycle synchronisation in the euro area countries, macroprudential policy on a national level might have to also deal with the side effects of a common monetary policy.

We are aware that our methodology focuses only on the interest rate changes, not the levels of interest rates, so this might underestimate the expansionary monetary policy with the use of quantitative easing after the GFC. When interest rates reach the zero lower bound and are not further lowered, the central bank might instead pursue quantitative easing (QE) programs to continue monetary easing. This is not accounted for in the current methodology. To acknowledge this limitation and as a robustness check, we rerun the calculations of the MPP for the USA, the euro area and the United Kingdom using the (quarterly average of) shadow interest rate (as developed by Wu - Xia 2016, 2017; Wu - Zhang 2019) as a substitute for the official interest rates of Fed, ECB and Bank of England, respectively. The shadow interest rate is not bounded by the zero-lower bound, and its level includes effects of unconventional policies like QE. Still, main central banks reached the zero lower bound only close to the end of our sample (from 2008/2009-2016). Until 2008/2009, shadow rates were very close to the official interest rates, but since then they have begun to deviate significantly i.e., shadow rates were significantly below the official interest rates.

It turns out that the average values of MPP ratios for all types of financial cycle measures with shadow rates are not much higher than the average MPP ratios with the official interest rates. ${ }^{11}$ On the one hand, this demonstrates the robustness of our results, confirming relatively low procyclicality of monetary policy. On the other hand, the calculations have to be assessed with caution, as part of the MPP increase might be due to the higher variability of the shadow rate, as compared to the official rates, which according to our methodology, might to some extent put an upward bias on the MPP values with shadow rates.

\section{DISCUSSION}

In our study, conflicting policy objectives arise most often when inflation is below the target and the credit cycle is in a boom. This is in line with the assessment of the negative effects of prolonged low interest rates (aimed at raising inflation) on the financial cycle. Channels of such effects might include the build-up of cyclical imbalances, increased search for yield behaviour, risk of asset price booms and misalignments, including on real estate markets (ESRB 2016). The negative interest rate policy has led to a gradual build-up of risk primarily on the bond market and in the banking sector in the countries with such interest rate policy (e.g., Kurowski - Rogowicz 2017). This, from both monetary and macroprudential policy perspectives, underlines the need to closely monitor market valuations, as well as strengthen early warning systems.

Further, we acknowledge that the financial cycle is influenced not only by interest rate changes, but also by other demand and supply shocks that might dampen or aggravate monetary

\footnotetext{
${ }^{11}$ For the US, the average MPP with the shadow rate was 0.12 ( 0.05 with the official interest rates), for the euro area it was $0.12(0.07)$ and for the UK $0.19(0.11)$.
} 
policy's impact on the financial cycle. In the post-crises periods the negative demand shocks were strongly affecting the economies in our sample. This called for expansive interest policy that was sustaining (revival of) both private demand and credit growth at the same time in a non-conflicting manner. The opposite situation might be more prevalent in the case of the negative supply side shocks e.g., when rapid rise in oil and gas prices, putting pressure on inflation, would not be accompanied with financial cycle exuberance. Thus, the role of the financial cycle variables in monetary policy may depend on the nature of the shocks during the analysed period and the fact that the business and financial cycles rarely coincide (Borio 2014).

Our results are also relevant in the discussion on the relations between monetary and macroprudential policies elaborated by Smets (2014), as the coordination framework mirrors the links between the objectives of both polices. The need for coordination is driven by the degree of synchronization and distinction between the business and financial cycles, as advocated by Fahr - Fell (2017). They find that each policy separately is the most efficient in achieving its primary goal(s). Our results partially conform to the view, as we show that leaving both policy objectives to be pursued by separate policies leads to limited existence of monetary policy procyclicality. So, the need for coordination between both policies could not be as urgent as initially expected. Thus, our results subscribe - in the spirit of Smets (2013) - to the view that monetary policy could focus on price stability alone (the Svensson's view), while macroprudential policy would also have to monitor and limit any, even if small, unintended negative impact of monetary policy (interest changes) on financial stability and on the financial cycle.

Yet, the coordination of both policies (e.g., the degree to which financial cycle considerations should be included into a monetary policy framework) requires further research. It would be necessary to assess the effectiveness of the (already applied and planned) macroprudential policy instruments in financial cycle stabilization. Additionally, the analysis of the strength and transmission channels of monetary policy's impact on the financial cycle would have to be taken into account. As Bayer et al. (2017) note, the macroeconomic impact of each policy has to consider that changes in other policies may influence the respective transmission mechanisms of monetary policy. Also results of Kim - Mehrotra (2017) suggest that the macroprudential and monetary policies work partly through related channels (e.g., both affecting aggregate demand), thus underlining the need to take into account the interrelations between the policies also in the implementation phase. So far neither literature, nor policy experiences has unequivocally determined which approach (coordination vs. separation of policies) results in higher net benefits (e.g., higher welfare) for the stability of the economy as a whole.

Lastly, we are aware of several limitations of our approach. First, it would be worthwhile to assess the nonlinearities related to the impact interest rates and inflation have on financial and asset price imbalances. Second, the analysed comovement between interest rates and the financial cycle is just a first step in exploring the causality links between monetary and macroprudential policies. This can be extended using VAR or structural models to observe the transmission mechanism of interest rate changes and observe the response of the financial cycle to a monetary policy shock. Further, as the macroprudential measures have been introduced only in recent years, closer to the end of our sample, exploring their concurrent impact on the financial cycle would be the next logical step. As most of them were of initially of tightening nature (see Budnik - Kleibl 2018 for EU), they could have depressed the revival of the financial cycle, mainly in the post-GFC period, supported conversely by low interest rates. Third, given the uniqueness of the euro area single monetary policy, applying hypothetical country-specific 
interest rates to the euro area countries in our sample could provide further insightful results. Fourth, we focus only on one direction of the relationship (monetary policy towards the financial cycle). It would be worthwhile to explore the reverse relation e.g., the impact of macroprudential instruments on inflation and the effectiveness of monetary policy. Those considerations point to the directions of further research.

\section{CONCLUSIONS}

Using a sample covering 21 countries and the euro area over the period of 1995Q1-2016Q2 we analysed the potential procyclicality of monetary policy (changes in official interest rates) towards the financial cycle and found it to be not a widespread phenomenon. We built a simple FSI that contains normalized gaps of four variables: the stock market index, credit/GDP, nominal house prices and debt-to-service ratio. Then, we compared the phases of the index and of its components (financial cycle measures) with interest rate changes. We found that, on average, the propensity of periods with potentially conflicting, objectives of price and financial stability (cyclical systemic risk) in all analysed countries was low. Moreover, the share of complementary periods in most analysed countries is higher than the share of the conflicting cases.

The results in the paper may also have additional implications for policymakers coordinating monetary and macroprudential policies. The level of potential monetary policy procyclicality indicates that macroprudential policy may have to target also amplified cyclical risks stemming from the negative side-effects of the monetary policy procyclicality. Thus far, this has not been explored in-depth in the literature. Yet, there are many caveats to such analysis. It is difficult to precisely estimate the phase of the financial cycle in real-time. Besides, the macroprudential policy operates at a lower frequency and in the medium-to long-term, while monetary policy might respond to the shorter-term fluctuations; thus, the time-inconsistency problem would limit the effectiveness of monetary policy in supporting financial stability. Moreover, the impact of monetary policy (interest rate changes) on systemic risk should be analysed not only in its cyclical, but also structural dimension, before making any policy decisions. What is more, we found that the average procyclicality ratios for a set of large economies are lower than those in several smaller economies. For a small open economy, with a relatively high financial cycle gap, exposure to capital flows and exchange rate volatility, the effectiveness of national monetary policy - and the space to manage conflicting policy objectives - might be additionally limited by the influence of global financial cycle. Moreover, the COVID-19 pandemic led to an aggressive monetary easing with the use of mainly different forms of QE programmes. This means that analysing monetary policy procyclicality in the future has to include the shadow rates to a wider extent, as well as focus more on the cyclical systemic risks fostered by the low interest rate environment, which has been prolonged for an even longer period.

\section{ACKNOWLEDGEMENTS}

The paper was written as a part of research (grant NCN MINIATURA 1) at SGH Warsaw School of Economics in 2017-2018, financed by the National Science Centre in Poland (No. 2017/01/X/HS4/01008). I am very grateful to dr Ł. Kurowski, prof. A. Savvides and participants 
of the West East Institute International European Academic Conference on Business \& Economics, Rome, Italy, November 13-15, 2017 for their helpful comments on the early draft of the paper. I explicitly stress that the opinions expressed herein are those of the author and do not reflect those of the associated institution.

\section{REFERENCES}

Agénor, P. R. - Pereira Da Silva, L. A. (2014): Macroprudential Regulation and the Monetary Transmission Mechanism. Journal of Financial Stability, 13: 44-63.

Albulescu, C. (2010): Forecasting the Romanian Financial Sector Stability Using a Stochastic Simulation Model. Romanian Journal of Economic Forecasting, 1: 81-98.

Angelini, P. - Neri, S. - Panetta, F. (2014): The Interaction Between Capital Requirements and Monetary Policy. Journal of Money, Credit and Banking, 46(6): 1073-1112.

Angelini, P. - Nicoletti-Altimari, S. - Visco, I. (2012): Macroprudential, Microprudential and Monetary Policies: Conflicts, Complementarities and Trade-Offs. Occasional Papers, No. 140, Bank of Italy.

Beau, D. - Clerc, L. - Mojon, B. (2012): Macroprudential Policy and the Conduct of Monetary Policy. Working Paper, No. 390, Banque De France.

Beyer, A. - Nicoletti, G. - Papadopoulou, N. - Papsdorf, P. - Rünstler, G. - Schwarz, C. - Sousa, J. Vergote, O. (2017): The Transmission Channels of Monetary, Macro- and Microprudential Policies and Their Interrelations. ECB Occasional Paper Series, No. 191.

Bjørnland, H. C. - Leitemo, K. (2016): Identifying the Interdependence Between US Monetary Policy and the Stock Market. Journal of Monetary Economics, 56(2): 275-282.

Borio, C. - Drehmann, M. - Gambacorta, L. - Jiménez, G. - Trucharte, C. (2010): Countercyclical Capital Buffers: Exploring Options. BIS Working Paper, No. 317.

Borio, C. - Drehmann, M. - Tsatsaronis, K. (2012): Characterising the Financial Cycle: Don't Lose Sight of the Medium Term! BIS Working Paper, No 380.

Borio, C. (2014): The Financial Cycle and Macroeconomics: What Have We Learnt? Journal of Banking \& Finance, 45(C): 182-198. https://doi.org/10.1016/J.Jbankfin.2013.07.031.

Budnik, K. - Kleibl, J. (2018): Macroprudential Regulation in the European Union in 1995-2014: Introducing a New Data Set on Policy Actions of a Macroprudential Nature. EBC Working Paper Series, No 2123.

Cevik, E. I. - Dibooglu, S. - Kutan, A. M. (2013): Measuring Financial Stress in Transition Economies. Journal of Financial Stability, 9(4): 597-611. https://doi.org/10.1016/j.jfs.2012.10.001.

Christiano, L. J. - Ilut, C. - Motto, R. - Rostagno, M. (2010): Monetary Policy and Stock Market Booms. Proceedings of the Federal Reserve Bank of Kansas City Economic Policy Symposium, Jackson Hole, pp. $85-145$.

Claessens, S. - Kose, M. A. -Terrones, M. E. (2011): How Do Business and Financial Cycles Interact? IMF Working Paper, No. 11/88.

Crowe, C. - Dell'Ariccia, G. - Igan, D. - Rabanal, P. (2013): How to Deal with Real Estate Booms: Lessons from Country Experiences. Journal of Financial Stability, 9: 300-319.

Dell'Ariccia, G. - Laeven, L. - Marquez, R. (2014): Real Interest Rates, Leverage, and Bank Risk-Taking. Journal of Economic Theory, 149: 65-99. 
Detken, C. - Weeken, O. - Alessi, L. - Bonfim, D. - Boucinha, M. M. - Castro, C. - Welz, P. (2014): Operationalizing the Countercyclical Capital Buffer. ESRB Occasional Paper, No. 5.

Drehmann, M. - Juselius, M. (2013): Evaluating Early Warning Indicators of Banking Crises: Satisfying Policy Requirements. BIS Working Papers, No. 421.

Dumičić, M. (2016): Financial Stability Indicators - The Case of Croatia. Journal of Central Banking Theory and Practice, 1: 113-140.

ECB (2018): Financial Stability Review. May.

ESRB (2016): Macroprudential Policy Issues Arising from Low Interest Rates and Structural Changes in the EU Financial System. November.

Fahr, S. - Fell, J. (2017): Macroprudential Policy - Closing the Financial Stability Gap. Journal of Financial Regulation and Compliance, 25(4): 334-359.

Gersl, A. - Jakubik, P. - Kowalczyk, D. - Ongena, S. - Peydró, J. L. (2015): Monetary Conditions and Banks' Behaviour in the Czech Republic. Open Economies Review, 26: 407-445.

Greenwood-Nimmo, M. - Tarassow, A. (2016): Monetary Shocks, Macroprudential Shocks and Financial Stability. Economic Modelling, 56: 11-24.

Hakkio, S. C. - Keeton, W.R. (2009): Financial Stress: What Is It, How Can It Be Measured, and Why Does It Matter? Federal Reserve Bank of Kansas City Economic Review, Second Quarter.

Hamilton, J. D. (2018): Why You Should Never Use the Hodrick-Prescott Filter. Review of Economics and Statistics, 100(5): 831-843.

Harding, D. - Pagan, A. (2001): Extracting, Analysing and Using Cyclical Information. MPRA Paper, No. 15.

Heider, F. - Saidi, F. - Schepens, G. (2018): Life Below Zero: Bank Lending under Negative Policy Rates. ECB Working Paper Series, No. 2173.

Hopkins, E. - Lindé, J. - Söderström, A. (2009): The Monetary Transmission Mechanism. Riksbank Economic Review, No. 2.

Igan, D. - Kabundi, A. - Nadal De Simone, F. - Tamirisa, N. (2017): Monetary Policy and Balance Sheets. Journal of Policy Modeling, 39(1): 169-184.

Iwanicz-Drozdowska, M. - Smaga, P. - Witkowski, B. (2017): Role of Foreign Capital in Stability of Banking Sectors in CESEE Countries. Finance a uver - Czech Journal of Economics and Finance, 67(6): 492-511.

Jakubík, P. - Slačík, T. (2013): Measuring Financial (In)Stability in Emerging Europe: A New Index-Based Approach. OENB Financial Stability Report, No. 25, June.

Jiménez, G. - Ongena, S. - Peydró, J. L. - Saurina, J. (2014): Hazardous Times for Monetary Policy: What Do Twenty-Three Million Bank Loans Say About the Effects of Monetary Policy on Credit RiskTaking? Econometrica, 82: 463-505.

Jong, R. M. - Sakarya, N. (2016): The Econometrics of the Hodrick-Prescott Filter. Review of Economics and Statistics, 98(2): 310-317.

Kim, S. - Mehrotra, A. (2017): Effects of Monetary and Macro-Prudential Policies - Evidence from Inflation Targeting Economies in the Asia-Pacific Region and Potential Implications for China. BOFIT Discussion Papers, No. 4/2017, Bank of Finland, Institute for Economies in Transition.

Klomp, J. - De Haan, J. (2012): Banking Risk and Regulation: Does One Size Fit All? Journal of Banking \& Finance, 36(12): 3197-3212.

Kollintzas, T. - Konstantakopoulou, I. - Tsionas, E. (2011): Stylized Facts of Money and Credit Over the Business Cycles. Applied Financial Economics, 21: 1735-1755. 
Kota, V. - Saqe, A. (2013): A Financial Systemic Stress Index for Albania.Working Paper, No. 03 (42), Bank of Albania.

Kurowski, Ł. - Rogowicz, K. (2017): Negative Interest Rates as Systemic Risk Event. Finance Research Letters, 22: 153-157.

Kurowski, Ł. - Smaga, P. (2018): Monetary Policy and Cyclical Systemic Risk - Friends or Foes? Prague Economic Papers, 27(5): 522-540.

Landier, A. - Sraer, D. - Thesmar, D. (2011): The Risk-Shifting Hypothesis: Evidence from Subprime Originations. TSE Working Paper, No. 11.

Lo Duca, M. - Peltonen, T. (2013): Assessing Systemic Risks and Predicting Systemic Events. Journal of Banking \& Finance, 37(7): 2183-2195.

Maddaloni, A. - Peydró, J. L. (2013): Monetary Policy, Macroprudential Policy, and Banking Stability: Evidence from the Euro Area. International Journal of Central Banking, 9(1): 121-169.

Malovaná, S. - Frait, J. (2016): Monetary Policy and Macroprudential Policy: Rivals or Teammates? Česká Národní Banka Working Paper Series, No. 6/2016.

Mérő, K. (2017): The Emergence of Macroprudential Bank Regulation: A Review. Acta Oeconomica, 67 (3): 289-309.

Miles, W. (2014): The Housing Bubble: How Much Blame Does the FED Really Deserve? Journal of Real Estate Research, 36(1): 41-58.

Nicolò, G. D. - Dell'Ariccia, G. - Laeven, L. - Valencia, F. (2010): Monetary Policy and Bank Risk Taking. IMF Staff Position Note, SPN/10/09.

Persson, M. (2009): Household Indebtedness in Sweden and Implications for Financial Stability - The Use of Household-Level Data. BIS Paper, No. 46.

Plašil, M. - Seidler, J. - Hlaváč, P. (2016): A New Measure of the Financial Cycle: Application to the Czech Republic. Eastern European Economics, 54(4): 296-318.

Rigobon, R. - Sack, B. (2004): The Impact of Monetary Policy on Asset Prices. Journal of Monetary Economics, 51(8): 1553-1575.

Rubio, M. (2016): Short- and Long-Term Interest Rates and the Effectiveness of Monetary and Macroprudential Policies. Journal of Macroeconomics, 47, Part A: 103-115.

Samarina, A. - Zhang, L. - Bezemer, D. (2017): Credit Cycle Coherence in the Eurozone: Was There a Euro Effect? Journal of International Money and Finance, 77: 77-98.

Shi, S. - Jou, J. B. - Tripe, D. (2014): Can Interest Rates Really Control House Prices? Effectiveness and Implications for Macroprudential Policy. Journal of Banking \& Finance, 47: 15-28.

Siņenko, N. - Titarenko, D. - Āriņš, M. (2014): The Latvian Financial Stress Index as an Important Element of the Financial System Stability Monitoring Framework. Baltic Journal of Economics, 13(2): 87-112.

Šlahor, L. - Rychtárik, S. - Bandúr, M. (2015): Financial Stability Considerations for Slovakia in the Context of ECB Monetary Stance. Procedia Economics and Finance, 30: 816-824.

Smets, F. (2013): Financial Stability and Monetary Policy: How Closely Interlinked? Sveriges Riksbank Economic Review, 3, Special Issue: 121-160.

Smets, F. (2014): Financial Stability and Monetary Policy: How Closely Interlinked? International Journal of Central Banking, 10(2): 263-300.

Szendrei, T. - Varga, K. (2017): FISS - A Factor Based Index of Systemic Stress in the Financial System. MNB Working Papers, No. 9.

Vermeulen, R. - Hoeberichts, M. - Vašíček, B. - Žigraiová, D. - Šmídková, K. - Haan, J. (2015): Financial Stress Indices and Financial Crises. Open Economies Review, 26: 383-406. 
Wu, J. C. - Xia, F. D. (2016): Measuring the Macroeconomic Impact of Monetary Policy at the Zero Lower Bound. Journal of Money, Credit, and Banking, 48(2-3): 253-291.

Wu, J. C. - Xia, F. D. (2017): Time Varying Lower Bound of Interest Rates in Europe. Chicago Booth Research Paper, No. 17-06.

Wu, J. C. - Zhang, J. (2019): A Shadow Rate New Keynesian Model. Journal of Economic Dynamics and Control, 107: 103728.

\section{APPENDIX}

\section{Data categories and sources}

\begin{tabular}{|c|c|c|}
\hline Category & Source & Link \\
\hline $\begin{array}{c}\text { Credit/GDP (quarterly data, credit } \\
\text { to the non-financial sector, all } \\
\text { sectors, market value) }\end{array}$ & BIS and national central banks & http://www.bis.org/statistics/ \\
\hline $\begin{array}{c}\text { Nominal house prices - NHP } \\
\text { (quarterly data, residential, } \\
\text { seasonally adjusted, index based in } \\
\text { 2010) }\end{array}$ & OECD, BIS & https://stats.oecd.org/ \\
http://www.bis.org/statistics/ \\
\hline $\begin{array}{c}\text { Stock market index - SMI } \\
\text { (quarterly average, closing levels, } \\
\text { natural logarithm) }\end{array}$ & $\begin{array}{c}\text { National stock exchanges, national } \\
\text { central banks, Bloomberg, Stooq }\end{array}$ & \\
\hline $\begin{array}{c}\text { Interest rate (official reference } \\
\text { interest rate set by the central } \\
\text { bank, daily average level in each } \\
\text { quarter) }\end{array}$ & National central banks & \\
\hline $\begin{array}{c}\text { Inflation (yoy quarterly data, CPI, } \\
\text { RPI or HICP - depending on the } \\
\text { given inflation target in the sample } \\
\text { country) }\end{array}$ & OECD and national central banks & http://stats.oecd.org/ \\
\hline $\begin{array}{c}\text { Debt service ratio - DSR (for the } \\
\text { private non-financial sector) }\end{array}$ & & https://data.oecd.org/price/ \\
inflation-cpi.htm
\end{tabular}

\footnotetext{
${ }^{12}$ Data for euro area DSR is proxied by GDP-weighted average of DSR of the euro area members in the sample.
} 